\title{
DEGLOBALIZATION - A SITUATIONAL PHENOMENON OR A STABLE WORLD TREND?
}

\section{Iryna Markovych}

Ternopil Ivan Pul'uj National Technical University 56 Ruska str., 46001 Ternopil, Ukraine

e-mail:soriraa@gmail.com

ORCID ID: https://orcid.org/0000-0003-4585-722X

\author{
Nataliia Bazhanova \\ Ternopil Ivan Pul'uj National Technical University \\ 56 Ruska str., 46001 Ternopil, Ukraine \\ e-mail: bazhanova_natalia@ukr.net \\ ORCID ID: https://orcid.org/0000-0001-6949-705X
}

OPEN 2 ACCESS (C) doij

\section{Article history:}

Received: May, 2020

1st Revision: June, 2020

Accepted: June, 2020

\section{JEL classification: F60}

\section{UDC:}

330.11

\section{DOI:}

https://doi.org/10.33108 /sepd2020.01.016

Abstract. The aim of the article is to identify trends in the world economy in terms of changes in periods of increasing globalization and deglobalization manifestations, supplementing them with a study of the factors that stimulate these manifestations. Economic-financial, social and political globalizations are singled out as planes of globalization processes development.

It is shown that economic and financial globalization is characterized by the intensity and conditions of movement of goods and services in international trade flows; organizational and economic transformations of entrepreneurship in the context of innovative changes in the world's economic development; investment component of the economies functioning; formation of a common financial market, etc.

Social globalization finds its expression through cross-cultural and behavioral aspects of interactions in the world; migration processes; the role of the information space in reformatting the world order, etc.

Political globalization is manifested in the peculiarities of the influence of the institutional factor on market structures; decision-making procedures at the national and international levels, etc.

The cyclical intensification of globalization and deglobalization manifestations in the world economy has been studied, which demonstrates the stability of the tendency to weaken the importance of fragmented supply chains in international trade.

It has been proven that the ability to adapt is especially important for companies to be able to use the opportunities that are open to them as actors in today's interconnected world, and not lose their potential under the influence of often contradictory forces, which are due to them.

Differences in perceptions of the benefits and threats of globalization forces by different population groups are shown, as well as changes in the geography of global demand, the drivers of skepticism about globalization are outlined, the most important of which are: inequality, and in the interstate context); certainty (vulnerability caused by the possible loss of national identity and its gradual replacement by cultural norms of other countries); impact (vulnerability due to difficult opportunities to counter the decisions and policies of international organizations and multinational companies). trade.

Keywords: globalization, deglobalization, national economy, international

Маркович I. Deglobalization - a situational phenomenon or a stable world trend? [Електронний ресурс] / Ірина Маркович, Наталія Бажанова // Соціально-економічні проблеми і держава. - 2020. - Вип.1(22). - С.16-24. - Режим доступу: http://sepd.tntu.edu.ua/images/stories/pdf/2020/20mibswt.pdf 


\section{Statement of the problem.}

Development of the world economy can be analyzed from the standpoint of a system approach and identified according to certain trends and patterns. In the time of unstable interdependencies between the elements of the world economic system, contradictory to globalization processes are becoming more and more pronounced. This causes the spread of globalization trends among scientists-economists and politicians.

\section{Analysis of recent research and publications.}

The works of individual scientists (for example, M. Kolb, M. Matters, A. CuervoCazurra), as well as analytic centres and organizations (the International Monetary Fund, the International Bank for Reconstruction and Development, the McKinsey Global Institute, and others) are devoted to the study of relationship between globalization and deglobalization forces.

\section{Unsolved aspects of the problem.}

As the global economic crisis of 2008-2009 laid a solid foundation for doubts about the unequivocally positive attitude to globalization, and the period of struggle against the COVID19 epidemic (2020) only added arguments to the need to reformat and balance national and global interests, relevance acquires research on the process of globalization of the world economic space.

\section{Task formulation.}

To analyze trends in the world economy from the standpoint of cyclical or chaotic periods of increasing globalization and deglobalization manifestations, supplementing them with the study of factors that stimulate these manifestations.

\section{Main material exposition.}

With the beginning of interstate movements of goods, capital, and people, the world economy gradually became globalized, although the intensity of globalization processes differed significantly in terms of time periods, regions, and countries.

Globalization is the word used to describe the growing interdependence of the world's economies, cultures, and populations, brought about by cross-border trade in goods and services, technology, and flows of investment, people, and information [1].

Investigating globalization processes, features of their course, preconditions, stimulators and disincentives, methodological measurement tools, possible consequences of individual manifestations of structural changes in the world, it is important to understand the main 3 planes in which these processes unfold:

1. Economic and financial globalization (intensity and conditions of movement of goods and services in international trade flows; organizational and economic transformations of entrepreneurship in the context of innovative changes in economic development of the world; investment component of economies' functioning; formation of a common financial market, etc.);

2. Social globalization (cross-cultural and behavioural aspects of interactions in the 
world; migration processes; role of the information space in reformatting the world order, etc.);

3. Political globalization (features of the influence of institutional factor on market structures; decision-making procedures at the national and international levels, etc.).

All these planes find intersection at many points, which allows us to speak of economic, financial, social and political globalization as various manifestations of general civilizational globalization processes.

Ambiguous and rather contradictory attitude to globalization has existed for a long time and each recession of the world economy and its entry into crisis provokes an increase in the number of supporters of the so-called "deglobalization", i.e. increasing the importance of domestic national interests in state decision-making.

Protectionism in many areas replaces the formation of globalized supply chains, the main advantage of which compared to domestic production is the ability to use the benefits of each of the countries included in the chain. The effectiveness of market diversification and fragmentation of production with international division is questioned and sharply criticized during the period of relative isolation of states due to quarantine measures to combat the spread of COVID-19 in many countries.

In the works of scientists, one can come across the opinion that certain countries or certain groups of the population of these countries may not experience the benefits that the supporters of globalization processes insist on (for example, [2]).

In summary, these thoughts boil down to the following: «Increased foreign competition leads to the disappearance of domestic companies and the firing of workers, who were previously shielded by barriers against foreign products and companies. The global diffusion of technologies alters traditional careers and expectations regarding relationships between workers, citizens, and firms. Increases in production and consumption contribute to environmental degradation and social exclusion. These costs induce some not only to question whether the benefits compensate for the costs, but also whether globalization has brought any benefits at all» [3].

A certain cyclical strengthening with further weakening of globalization manifestation, in particular in the dynamics of international trade, has been observed over the last century (Fig. 1).

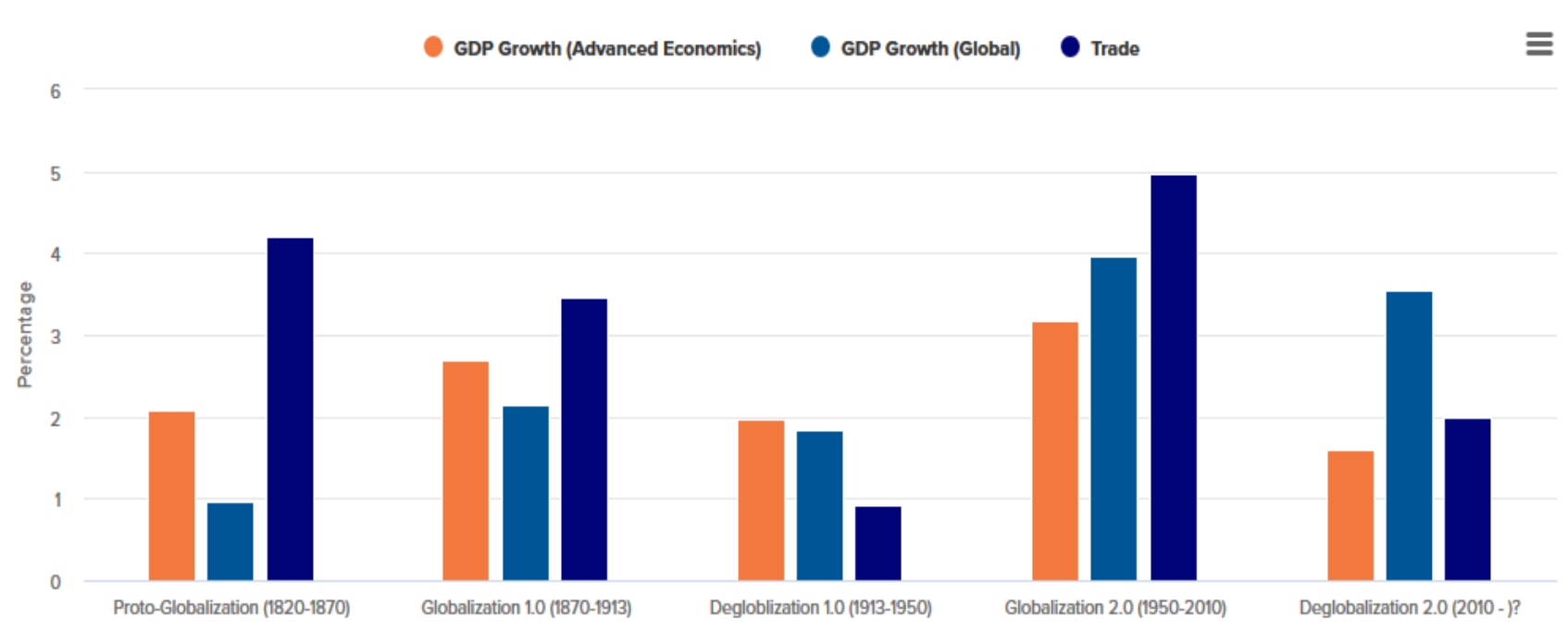

Fig.1 Cycles of globalization and deglobalization

Source: [4] 
Of course, Globalization 2.0 was mainly conditioned due to two main forces technological improvements and breakthroughs, as well as manifestations of economic liberalization. The combination of accelerating the use of communication tools with institutional deregulation of markets in the direction of strengthening liberalization trends has resulted in a rapid increase in trade and investment turnover.

Since the UK referendum on Brexit, the US presidential election (2016), and the election of other political figures in other countries, it has become clear that the pressure of globalization in public policies in the world is only growing. If before 2008-2009 it could be said that the general civilizational vector of the economy, in particular the European one, has been a large-scale deregulation of markets by the state, dominance of market globalization forces over the state ones, today the world has another challenge to reassess the ability to balance national and global priorities.

The complexity of a networked system, ranging from the social to the economic, to the political, is associated with its structural topology. Interdependencies are critical for understanding the trade-offs between efficiency and robustness in such systems. While public debate questions whether the public or private sector should be regulated, reformed, or ultimately empowered, the role of the interdependencies of these sectors with their global counterpart is a crucial dimension in the system behavior yet often overlooked [5].

Disagreement over the benefits and threats of globalization is due to differences in perceptions of these effects by different social and political groups. For example, a change in the tariff regulation of international trade through a transmission mechanism affects prices for foreign goods, i.e. a change in prices can be considered a direct consequence of globalization, however, such a relationship is not direct. Some focus on the losses of countries in the development of national production through the replacement of its potential results by foreign goods. Simultaneously, there is strong evidence that trade profits are greatest for poor consumers [6].

At the same time, the negative impact of globalization may be the reduction of workplaces in developed countries, which are filled by migrants who are satisfied with lower wages than those expected by people living in these countries. While accumulating the benefits of globalization, we should not forget about the price of positive changes and the costs of globalization. Such selectivity of perception can often form a persistent biased attitude to the quality of the consequences of globalization processes.

Looking at the statistics on the peculiarities of formation and functioning of fragmented production chains, it becomes clear that a stable trend is the dependence of their efficiency on highly skilled labour resources. That is, it can be argued that the growing role is played not by the price advantage of labour resources of individual countries, but their quality and professional opportunities.

The ability to adapt is especially important for companies to be able to use the opportunities that are open to them as actors in today's interconnected world, and not lose their potential under the influence of often contradictory forces, which are due to them.

One of the forces, which transform global value chains, is the change of geography of global demand. The map of global demand, as it has shifted sharply to developed economies, is changing - and value chains are reconfiguring as companies decide how to compete in many major consumer markets that are now scattered around the world. The McKinsey Global Institute estimates that emerging markets will consume nearly two-thirds of the world's manufactured goods by 2025. By 2030, developing countries are projected to cover more than half of the world consumption. These countries continue to deepen their participation in 
global flows of goods, services, finance, people and data [7].

Fig. 2 shows the share of developed economies in the world consumption by region, and Fig. 3 shows data on the share of economies of individual groups of countries in the world consumption by region.

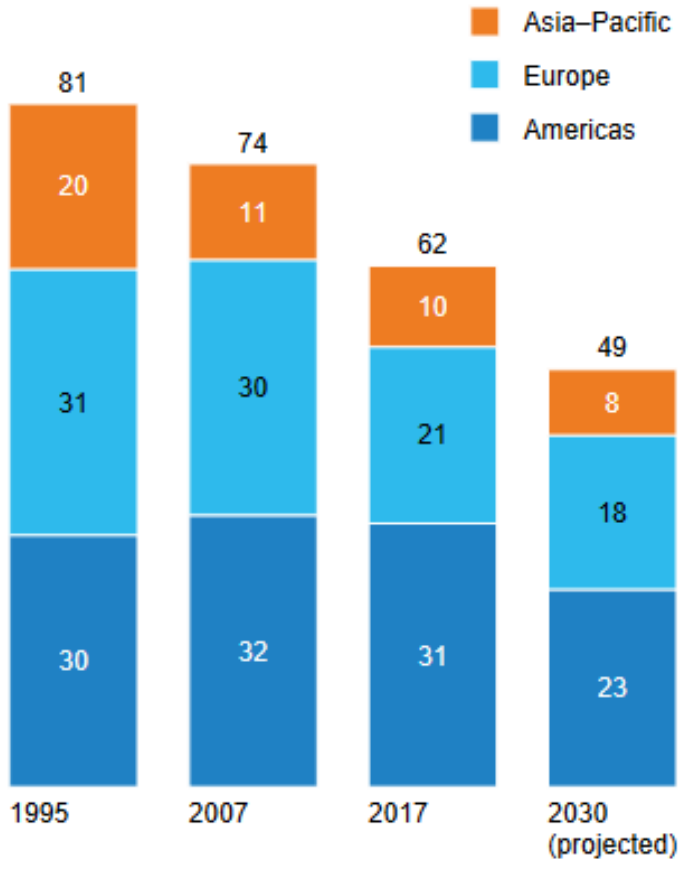

Fig. 2 Share of developed economies in the world consumption by region, $\%$ Source: [7, p.11]
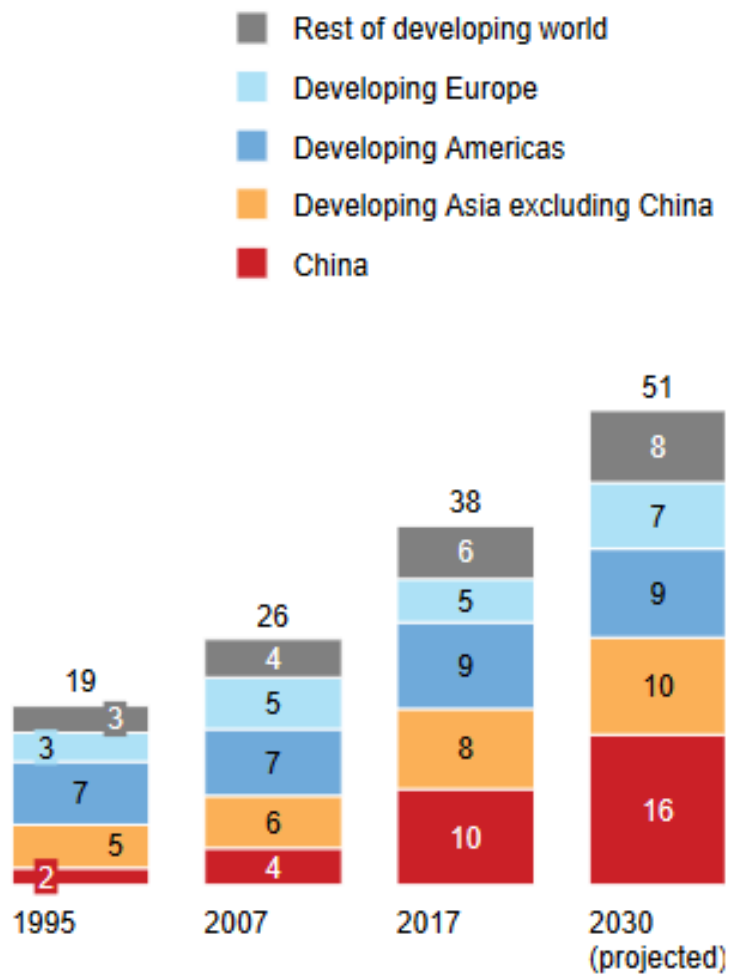

Fig.3 Shares of economy in the world consumption by region, $\%$ Source: [7, p.11] 
Thus, we can talk about a certain regionalization of consumption and production.

Considering the driving forces of scepticism about globalization, we can identify 3 main [3]:

1. Inequality (vulnerability caused by uneven distribution of income both within the country between different social groups and in the interstate context);

2. Certainty (vulnerability caused by the possible loss of national identity and its gradual replacement by cultural norms of other countries);

3. Impact (vulnerability caused by difficult opportunities to counter the decisions and policies of international organizations and multinational companies).

It is clear that the totality of these drivers is often amplified by populist influences exerted on society by certain political forces, exaggerating the importance of some of them, or, conversely, denying the negative manifestations of these processes. For example, uneven income distribution has a statistical side of assessment, and may have an emotional side that is easier to generate and manipulate.

Speaking of "certainty" or "belonging" as another powerful driver of globalization trends, it is obvious that it will increase as a result of migratory changes. The blurring of clear national cultural boundaries and often inconspicuous incorporation of cultural elements of different countries into the national culture of an individual country has been quite transparent over the last 20-30 years.

Considering the element of "influence" in the system of drivers of globalization, its supporters confidently argue that the influence of intergovernmental organizations and multinational companies on national governments of individual countries is extremely powerful and largely determines national development strategies. Dependence, especially financial and security, as it arises in states on the international community and the organizations that are formed by it, can be critical and completely eliminate the autonomy in government decision-making.

\section{Conclusions and recommendations for further researches.}

Thus, development of the world economy is neither clearly defined nor can be easily predicted. Due to the complex interconnections that can be relatively easily disrupted by both cyclical crises and institutional functioning of individual countries, balancing of globalization and deglobalization impacts is very unstable, requiring further research in this area.

\section{Author details (in Russian) ДЕГЛОБАЛИЗАЦИЯ - СИТУАТИВНОЕ ЯВЛЕНИЕ ИЛИ СТОЙКИЙ МИРОВОЙ ТРЕНД?}

\section{Ирина Марковыч}

Тернопольский национальный технический университет имени Ивана Пулюя

ул. Русская, 56, г. Тернополь, 46001, Украина e-mail:soriraa@gmail.com

ORCID ID: https://orcid.org/0000-0003-4585-722X

\section{Наталия Бажанова}

Тернопольский национальный технический университет имени Ивана Пулюя

ул. Русская, 56, г. Тернополь, 46001, Украина e-mail: bazhanova_natalia@ukr.net ORCID ID: https://orcid.org/0000-0001-6949-705X 
Аннотация. Задачей статьи является выявление тенденций в мировой экономике с точки зрения изменений периодов усиления глобализачиионных и деглобализачионных проявлений, дополнив их исследованием факторов, которые эти проявления стимулируют.

Выделено экономико-финансовую, сочиальную и политическую глобализацию как плоскости развертывания общемировых глобализационных процессов.

Показано, что экономико-финансовая глобализачии характеризует интенсивность и условия движения товаров, услуг в международных торговых потоках; организационноэкономические трансформаџии предпринимательства в контексте инновационных изменений экономического развития мира; инвестищионная составляющая функционирования экономик; формирование общего рынка и т.д.

Сочиальная глобализачия находит свое выражение через кросс-культурные и поведенческие аспекты взаимодействий в мире; миграционные прочессы; роль информационного пространства в переформатировании мирового порядка и др.

Политическая глобализаџия проявляется в особенностях воздействий институционального фактора на рыночные структуры; процедурах принятия решений на национальном и межнациональном уровнях и т.д.

Исследована ичкличность усиления глобализациионных и деглобализационных проявлений в мировой экономике, демонстрирует устойчивость тенденции ослабления значимости фрагментированных производственно-сбытовых иепочек в международной торговле.

Доказано, что способность к адаптащии особенно остро необходима компаниям, чтобы быть в состоянии использовать те возможности, которые отрытые перед ними как перед актерами современного взаимосвязанного мира, и не потерять свой потенциал под действием часто контрадикторных сил, которым и обусловленьл.

Показано различия в восприятии выгод и угроз глобализационных сил различными группами населения, а также исследовано изменение географии глобального спроса, определены движущие силь скептицизма относительно глобализации, среди которых наиболее значимые следующие: неравенство (уязвимость, обусловленная неравномерным распределением доходов как внутри страны между различными социальными группами, так и в межгосударственном разрезе) определенность (уязвимость, обусловленная возможной потерей национальной идентичности и постепенная ее замена культурными нормами других стран); влияние (уязвимость, обусловленная осложненными возможностями противодействовать решениям $u$ политике международных организаций $u$ многонациональных компаний).

Ключевые слова: глобализация, деглобализация, национальная экономика, международная торговля.

\section{Author details (in Ukrainian) ДЕГЛОБАЛІЗАЦІЯ - СИТУАТИВНЕ ЯВИЩЕ ЧИ СТІЙКИЙ СВІТОВИЙ ТРЕНД?}

\section{Ірина Маркович}

Тернопільський національний технічний університет імені Івана Пулюя, вул. Руська, 56, м. Тернопіль, Україна, 46001 e-mail:soriraa@gmail.com ORCID ID: https://orcid.org/0000-0003-4585-722X

\section{Наталія Бажанова}

Тернопільський національний технічний університет імені Івана Пулюя, вул. Руська, 56, м. Тернопіль, Україна, 46001 e-mail: bazhanova_natalia@ukr.net ORCID ID: https://orcid.org/0000-0001-6949-705X 
Анотація. Завданням статті є виявлення тенденцій у світовій економіці з точки зору змін періодів посилення глобалізаційних та деглобалізаційних проявів, доповнивщи їх дослідженням факторів, які ияі прояви стимулюють.

Виділено економіко-фінансову, соціальну та політичну глобалізацію як площиини розгортання загальносвітових глобалізаційних процесів.

Показано, щзо економіко-фінансова глобалізацію характеризують інтенсивність та умови руху товарів, послуг у міжнародних торгівельних потоках; організаційно-економічні трансформації підприємництва в контексті інноваційних змін економічного розвитку світу; інвестиційна складова функціонування економік; формування спільного фінансового ринку $i$ m. $\partial$.

Сочіальна глобалізачія знаходить своє вираження через крос-культурні та поведінкові аспекти взаємодій у світі; міграчійні прочеси; роль інформаційного простору у переформатуванні світового порядку та ін.

Політична глобалізація проявляється у особливостях впливів інституційного фактору на ринкові структури; процедурах прийняття рішень на національному та міжнаціональному рівнях і т..

Досліджено ичиклічність посилення глобалізаційних та деглобалізаційних проявів у світовій економіці, щзо демонструє стійкість тендениії послаблення вагомості фрагментованих виробничо-збутових ланџюжків у міжнародній торгівлі.

Доведено, щзо здатність до адаптащії особливо гостро необхідна компаніям, щзоб змогти використати ті можливості, які відриті перед ними як перед акторами сучасного взаємопов'язаного світу, та не загубити свій потенциіал під дією часто контрадикторних сил, щуо ним і зумовлені.

Показано відмінності у сприйнятті вигод та загроз глобалізачійних сил різними групами населення, а також досліджено зміну географії глобального попиту, окреслено рушійні сили скептицизму щцодо глобалізаџії, серед яких найбільш вагомі наступні: нерівність (вразливість, зумовлена нерівномірним розподілом доходів як в межах краӥни між різними соціальними групами, так $і$ в міждержавному розрізі); визначеність (вразливість, зумовлена можливою втратою національної ідентичності та поступова ї̈ підміна культурними нормами інших країн); вплив (вразливість, зумовлена ускладненими можливостями протидіяти рішенням та політиці міжнародних організацій та багатонаціональних компаній).

Ключові слова: глобалізація, деглобалізація, національна економіка, міжнародна торгівля

\section{Appendix A. Supplementary material}

Supplementary data associated with this article can be found, in the online version, at

http://sepd.tntu.edu.ua/images/stories/pdf/2020/20mibswt.pdf

\section{Funding}

The authors received no direct funding for this research.

\section{Citation information}

Markovych, I. \& Bazhanova, N. (2020) Deglobalization - a situational phenomenon or a stable world trend? Sotsialno-ekonomichni problemy i derzhava [Socio-Economic Problems and the State] (electronic journal), Vol. 22, no. 1, pp. 16-24. Available at: http://sepd.tntu.edu.ua/images/stories/pdf/2020/20mibswt.pdf

\section{References}

1. Kolb, M. (2018). What is globalization? And how has the global economy shaped the United States?Washington: Peterson Institute for International Policy. Retrieved from https://www.piie.com/microsites/globalization/what-is -globalization. 
2. Rodrik, D. (1997). Trade, social insurance, and the limits to globalization (No. w5905). National Bureau of Economic Research.

3. Cuervo-Cazurra, Alvaro \& Doz, Yves \& Gaur, Ajai (2020). Skepticism of Globalization and Global Strategy: Increasing Regulations and Countervailing Strategies. Global Strategy Journal.

4. Bob Swarup, Macro Matters (2015) Camdor Global Advisors https://app.everviz.com/embed/juiXJrYS/?redirected-from-hs.

5. Balsa-Barreiro, J., Vié, A., Morales, A.J. et al.(2020) Deglobalization in a hyper-connected world. Palgrave Commun 6, 28. https://doi.org/10.1057/s41599-020-0403-x.

6. Fajgelbaum, Pablo D. and Amit K. Khandelwal. (2016). "Measuring the Unequal Gains from Trade." The Quarterly Journal of Economics 131 (3): 1113-180.

7. Lund, S., Manyika, J.,Woetzel, J., Bughin, J., Krishnan, M., Seong, .J, \& Muir, M. (2019). Globalization in transition: The future of trade and value chain. Report, New York: McKinsey Global Institute. 